\title{
Blood management in fast-track orthopedic surgery: an evidence-based narrative review
}

\author{
Federico Pennestrì , Nicola Maffulli ${ }^{2,3,4^{*}}$ (D), Paolo Sirtori ${ }^{1}$, Paolo Perazzo ${ }^{1}$, Francesco Negrini ${ }^{1}$, Giuseppe Banfi ${ }^{1,5}$ and \\ Giuseppe M Peretti ${ }^{1,6}$
}

\begin{abstract}
Background and purpose: Innovations able to maintain patient safety while reducing the amount of transfusion add value to orthopedic procedures. Opportunities for improvement arise especially in elective procedures, as long as room for planning is available. Although many strategies have been proposed, there is no consensus about the most successful combination. The purpose of this investigation is to identify information to support blood management strategies in fast-track total joint arthroplasty (TJA) pathway, to (i) support clinical decision making according to current evidence and best practices, and (ii) identify critical issues which need further research.

Methods and materials: We identified conventional blood management strategies in elective orthopedic procedures. We performed an electronic search about blood management strategies in fast-track TJA. We designed tables to match every step of the former with the latter. We submitted the findings to clinicians who operate using fast-track surgery protocols in TJA at our research hospital.

Results: Preoperative anemia detection and treatment, blood anticoagulants/aggregants consumption, transfusion trigger, anesthetic technique, local infiltration analgesia, drainage clamping and removals, and postoperative multimodal thromboprophylaxis are the factors which can add best value to a fast-track pathway, since they provide significant room for planning and prediction.

Conclusion: The difference between conventional and fast-track pathways does not lie in the contents of blood management, which are related to surgeons/surgeries, materials used and patients, but in the way these contents are integrated into each other, since elective orthopedic procedures offer significant room for planning. Further studies are needed to identify optimal regimens.
\end{abstract}

Keywords: Blood management, Fast-track surgery, Orthopedics, Joint replacement, Health care value, Ethics

\section{Introduction}

The demand for total joint arthroplasty (TJA) is going to increase between 174 and $673 \%$ by 2030 [1, 2]. In the USA, orthopedic procedures account for up to $10 \%$ of all packed-red cell transfusions in a year, 39\% of which are used in TJA [3]. Blood loss can be extensive, and allogenic blood transfusion (ABT) is commonly performed. ABTs are associated with risks and complications [3-7]: to try

\footnotetext{
* Correspondence: n.maffulli@gmul.ac.uk

2Department of Musculoskeletal Disorders, School of Medicine and Surgery, University of Salerno, Fisciano, Italy

${ }^{3}$ San Giovanni di Dio e Ruggi D'Aragona Hospital "Clinica Orthopedica"

Department, Hospital of Salerno, Salerno, Italy

Full list of author information is available at the end of the article
}

and prevent them, it is necessary to invest in increasingly expensive safety procedures [8]. Moreover, the potential side effects of ABTs also impact social costs [9], accounting for the high economic cost of ABTs.

Innovations able to maintain patient safety while reducing the amount of ABTs therefore add value to orthopedic surgery procedures, where value is defined as outcomes achieved per money spent [10]. Opportunities for improvement arise especially in elective procedures, where room for planning is available. Indeed, experience of blood management in 2511 elective procedures reduced the amount of ABTs without increasing the number of recoveries and readmissions, generating an annual saving of $\$ 480,000$ [11].

(c) The Author(s). 2019 Open Access This article is distributed under the terms of the Creative Commons Attribution 4.0 International License (http://creativecommons.org/licenses/by/4.0/), which permits unrestricted use, distribution, and 
Blood management is a pillar of innovative health care models such as bundled payments [12] and fast-track pathways [13-15], as perioperative coordinated care is associated to a better and quicker recovery [15]. Accurate blood management can contribute to home discharge of 85-year-old patients 3 days after surgery[16], as well as to safely perform procedures in outpatient settings [17].

Although many strategies and algorithms have been proposed to reduce ABTs, there is no consensus about the most successful combination, given the different opinions over the same procedure, and the need to adapt the procedures to the characteristics of individual patients [18-20].

The purpose of this investigation is to identify information to support blood management strategies in fasttrack TJA pathway, to (i) support clinical decision making according to current evidence and best practices, and (ii) identify critical issues which need further research.

Reviews on blood management in orthopedics surgery [3], elective orthopedic surgery [8], total hip and knee arthroplasty $[18,21]$, and lower limb joint arthroplasty in a bundled payment [11] have been published. However, no review, to our knowledge, focuses on blood management in fast-track orthopedic pathways, except for general European Guidelines on perioperative venous thromboembolism prophylaxis [22].

Such a review should be helpful in two ways: first, by elaborating a synthesis on what has been published on the topic; second, by pointing out which parts of the perioperative process offer room for improvement.

\section{Materials and methods}

We proceeded in four steps.

First, we identified conventional blood management strategies in elective orthopedic procedures, to achieve a general road map to support the research on fast-track innovations. Six articles addressed the perioperative approach to the topic $[3,8,9,18,21,23]$. To provide a clear roadmap and adhering to previous recommendations [24-26], the strategies were divided in preoperative, intraoperative, and postoperative [27].

Second, we searched PubMed, Embase, Ebsco host, and Cochrane reviews for blood management strategies related to fast-track total joint arthroplasty, using the following keywords: fast(-)track surgery, orthop(a)edics, total joint arthroplasty, blood, blood management. After removing duplicates and studies not related to TJA procedures, 16 articles were eligible. These were read in full text to ensure their consistency with a fast-track TJA pathway.

Third, we designed tables to match every step of the perioperative process with information from the fast- track literature. In each table, information reported in the central column is therefore coming from conventional procedures. When it was not possible to fill the relevant column of the tables with information on fasttrack joint arthroplasty arising from the second step, we performed a further search on the topic using PubMed, Embase, Ebsco host and Cochrane reviews databases, bibliographies, and articles suggested by colleagues. These results-which are useful both for clinical and further research-are highlighted in the table with a *.

Fourth, we submitted the information reported in the right column to the opinion of clinicians who operate using fast-track surgery protocols for TJA at our hospital, to (i) check whether the information was sound, (ii) offer them opportunities for improvement, and (iii) identify practices which they already used, as such practices may be not reported in the published literature.

We acknowledge that steps three and four prevent the research from being entirely reproducible, which represents the main limitation of our study, but we believe this disadvantage to be offset by the advantage of providing information which can be missed with conventional research. We therefore opted for a narrative rather than a systematic review. Accordingly, we have adopted four of the six Cochrane recommendations for a systematic review27 (Table 1).

All searches were completed by January 21st, 2019.

\section{Results}

\section{Preoperative blood management}

Preoperatively, patients are thoroughly assessed, to decide whether to include them in an accelerated pathway, to plan clinical contingencies, and to educate the patients to take active part in the process. All are key steps in a successful fast-track design (Table 2).

\section{Intraoperative blood management}

Intraoperative management plays the most important role in safety, blood loss minimization, and early recovery (Table 3) [18].

Several studies have also investigated the role of intraoperative intermittent pneumatic compression devices (IPCDs) in preventing postoperative venous thromboembolism (VTE), but we report them in the following section because of their association with postoperative pharmacological prophylaxis.

\section{Postoperative blood management}

Fifty percent of the total blood loss in TKA occurs postoperatively [165], especially within the first $4 \mathrm{~h}$ (Table 4 ) [166].

Postoperative thromboprophylaxis is the step of perioperative management which received the greatest focus 
Table 1 Cochrane guidelines for systematic review

\begin{tabular}{lll}
\hline 1 Formulation of a clear question & $\begin{array}{l}\text { Which procedures support the implementation of blood } \\
\text { management in fast-track total joint arthroplasty? }\end{array}$ \\
\hline 2 Exhaustive and reproducible research of all relevant information & Partly reproducible, non-exhaustive. \\
(published and unpublished studies) concerning the question & Systematic selection of eligible studies on the basis of pre-defined \\
inclusion criteria & $\begin{array}{l}\text { All papers had to be related to fast-track pathways or } \\
\text { accelerated procedures, and had to be written in English } \\
\text { at least in the abstract. } \\
\text { Detailed information is reported in the PRISMA diagram } \\
\text { before the end of introduction. }\end{array}$ \\
$\begin{array}{ll}5 \text { Analysis of the methodological quality of included studies } \\
\text { Quantitative or qualitative synthesis of the information according }\end{array}$ & $\begin{array}{l}\text { No. } \\
\text { to the nature, complexity of the question and availability of data }\end{array}$ & $\begin{array}{l}\text { To facilitate reading, qualitative and quantitative } \\
\text { information is synthesized and summarized in tables. } \\
\text { Information about fast-track procedures is matched } \\
\text { with every single step of the general orthopedic blood } \\
\text { management strategy. } \\
\text { different studies }\end{array}$ \\
\hline
\end{tabular}

in fast-track surgery [129]. For practical reasons, we report findings about it in separate tables.

A prospective clinical study of 632 primary TJA patients evaluated the best combination between mechanical treatment (compression) and pharmacological chemoprophylaxis (aspirin and/or low molecular weight heparin) to prevent postoperative thromboembolic events (Table 5) [193].

The evaluation was performed answering four questions.

According to these results, the authors advocate routine use of mobile mechanical compression devices, which are able to prevent those VTEs and complications associated with chemical anticoagulants. This is consistent (i) with recommendations of the American Academy of Orthopedic Surgeons and the American College of Chest Physicians [194, 195], (ii) with a retrospective study of 3379 patients which confirmed mechanical treatment with IPCD to be a fast, easy, cheap, and safe support to postoperative multimodal approach [196], and (iii) with clinical pillars for TJA in a bundled payment paradigm [12].

With regard to accelerated pathways, the European Guidelines on VTE prevention were formulated crossreferencing the risk of the patient with the risk of the procedure, adopting Caprini score as an assessment criterion [22, 197] $(*)$.

We summarize them in the following table (Table 6).

The benefits of early mobilization and the combination between mechanical measures and aspirin are confirmed by other studies, both in fast-track [198] (*) and in conventional pathways [199].

The same guidelines underline the option, in selected procedures, to limit thromboprophylaxis treatment only to the period of hospitalization, and suggest to extend the treatment to up to 4 weeks in high-risk patients and procedures.
The first recommendation is based on a weak level of evidence $(2 \mathrm{C})$, but is supported by a large prospective study on 17,582 fast-track TJA procedures according to which 90-day incidence of VTE after in-hospital treatment was only $0.40 \%$ [53] $\left(^{*}\right)$. On the contrary, the second recommendation is based on a moderate level of evidence (2B), and supports the hypothesis of the prospective study: extended treatment for LOS more than 5 days and high-risk patients is strongly recommended.

Other studies suggest warfarin-based chemoprophylaxis for 6 weeks after THA [200], as well as fish oil as a cost-effective supplement to aspirin after TKA [201], prompting for prospective studies to confirm these suggestions.

\section{Discussion and limitations}

The purpose of this investigation was to identify information to support blood management strategies in fasttrack TJA pathways. The investigation confirmed the lack of comprehensive reviews on the topic, which we divided according to recommendations in preoperative, intraoperative, and postoperative.

The need for blood transfusions remains the most significant predictor of a longer stay (more than 3 days) also within accelerated pathways, occurring between $12 \%$ and $22 \%$ of THA and TKA. However, it seems not to compromise a high patient satisfaction, a fundamental assessment of quality in fast-track procedures. Waiting for blood transfusions is indeed one of the main reasons for a delay in discharge.

Identifying the reasons behind it makes it possible to assess the best clinical and logistical solution for the patient, starting preoperatively. The need for transfusion is associated with age, comorbidities, ASA score, and anemia (with iron deficiency as the most common and reversible cause). In general, a classic transfusion trigger 
Table 2 Preoperative blood management

\begin{tabular}{|c|c|}
\hline Content & Conventional studies, guidelines, and recomm \\
\hline \multirow{2}{*}{$\begin{array}{l}\text { Anemia and iron deficiency treatment } \\
\text { Since preoperative and postoperative anemia } \\
\text { are generally related, we refer to the latter in } \\
\text { the present section. }\end{array}$} & Anemia standards and detection \\
\hline & $\begin{array}{l}\text { Patients undergoing TKA should meet } \\
\text { standard criteria regarding the minimum } \\
\text { preoperative } \mathrm{Hb}[28-30] \text {. } \\
\text { Otherwise, surgery should be postponed [29]. } \\
\text { Recent guidelines recommend preoperative } \\
\text { correction of anemia and iron deficiency in al } \\
\text { patients with a } \mathrm{Hb}<13 \mathrm{~g} / \mathrm{dL} \text { [30]. } \\
\text { Preoperative assessment of anemic patients } \\
\text { should be performed between } 30 \text { and } 60 \\
\text { days before the procedure, in order to } \\
\text { investigate the cause and plan the ideal } \\
\text { treatment [24-26, 29,32-34]. }\end{array}$ \\
\hline
\end{tabular}

Blood thinners (antiplatelet, anticoagulant, antithrombotic agents)
Iron deficiency treatment

Iron-deficiency anemia is the main cause of low $\mathrm{Hb}[38,39]$.

This is why preoperative iron supplementation is highly suggested in orthopedic procedures, alone or together with intraoperative tranexamic acid (TXA) [40, 41]. $\left(^{*}\right)$ Studies report intravenous (IV) iron therapy to be safe and dominate on oral, in particular with patients with malabsorption such as coeliac disease [32, 42,43].

When using oral supplements for iron storage, a daily dose of $100 \mathrm{mg}$ elemental iron is recommended for 2 to 6 weeks before surgery.

When using IV iron supplementation, requirements can be estimated using the Ganzoni equation [44].

These drugs have a key role in preventing cardiac and vascular events [47]. To normalize bleeding, they are usually stopped a few days before surgery [8]...

... But patients at high cardiovascular risk should not stop aspirin in the perioperative period [48].

Given that cardiovascular disease is common in patients planning to undergo to TKA, both the continuation and the discontinuation of antiplatelet therapy can be associated with major risks, depending on patient characteristics, severity of the procedure and estimated time of immobilization $[8,49,50]$. The management of these medications in the perioperative setting should be adapted to the single patient according to cardiologist,
Fast-track setting

Pre- and postoperative $\mathrm{Hb}$ levels (together with the subsequent need for transfusions) play a role on fast-track TJA postoperative outcomes, Length of Stay (LOS) and patient satisfaction [15, 35].

Preoperative anemia is frequently associated with prolonged LOS, 90-day re-admission and blood transfusions, preventing fast-track TJA to express full value both in THA and TKA pro cedures $[31,36]\left(^{*}\right)$.

549 fast-track TJA procedures on patients aged $\geq 85$ years revealed blood-related issues such as postoperative anemia, blood transfusions, and mobilization to be the most relevant medical cause of more than 4 days LOS (27.3\%), where preoperative anemia had no significant impact.

Preoperative anemia was instead one of the main medical causes of readmissions within 90 days, together with suspected but disproved thromboembolic events. Authors concluded that fast-track TJA aiming at 3 days median LOS and discharge to home is feasible in most patients aged $\geq 85$ years, provided attention to pre- and post-operative anemia [16].

With regard to THA, authors show a weak but significant correlation between post-operative $\mathrm{Hb}$ and early functional recovery (6-min walk test) in 65 year-old patients, while they did not find any influence between the former and other functional criteria nor quality of life [37].

Studies on 882 unselected fast-track THA/TKA patients confirmed anemia to be prevalent in elderly patients and to be associated with increased transfusion risk and postoperative morbidity.

Iron deficiency is confirmed to be the most common and reversible cause [45].

Fast-track THA non-anemic patients with iron deficiency were supplemented with oral highly absorbable Sideral ${ }^{\circledR}$ Forte (at least) 4 weeks before surgery. They had a smaller decline in post-operative $\mathrm{Hb}$, shorter hospital stay and reduced blood transfusions, generating a saving of $1763.25 €$ per patient. Therefore, preoperative sucrosomial iron ${ }^{\circledR}$ is a cost-effective solution for fast-track THA surgery [46]. $\left(^{*}\right)$

Preoperative use of anticoagulant agents needs important evaluations in fast-track TJA too $[51,52] .\left(^{*}\right)$

A study on the incidence of stroke within 30-days after 24.682 fast-track TJA found preoperative use of anticoagulant treatment to be the most important risk factor, together with age $\geq 85$. Anemia was also included, but not significant.

It is therefore important to check for the use of preoperative anticoagulants, and anemia, to avoid cardiovascular perioperative events in elderly patients [53]. $\left.{ }^{*}\right)$ 
Table 2 Preoperative blood management (Continued)

\begin{tabular}{|c|c|c|}
\hline Content & Conventional studies, guidelines, and recommendations & Fast-track setting \\
\hline & orthopedic surgeon, and anesthesiologist [18]. & \\
\hline $\begin{array}{l}\text { Transfusion protocol agreement } \\
\text { Although transfusion is a postoperative } \\
\text { intervention, establishing the trigger must be } \\
\text { done before surgery. }\end{array}$ & $\begin{array}{l}\text { Reasons to variate transfusion practice in } \\
\text { orthopedic surgery are not well understood. } \\
\text { In case of elective surgery, the need for } \\
\text { allogenic transfusion was said to predictable } \\
\text { in } 97.4 \% \text { of the cases, according to (i) } \\
\text { preoperative anemia, (ii) perioperative blood } \\
\text { loss, (iii) transfusion trigger [54]. } \\
\text { A survey on clinicians and hospitals in the UK } \\
\text { showed transfusion triggers after TJA to } \\
\text { variate between } 6 \text { to } 11 \mathrm{~g} / \mathrm{dL} \text {, calling for } \\
\text { shared evidence-based guidelines to improve } \\
\text { practice and avoid waste [55]. } \\
\text { This is consistent with results from a previous } \\
\text { international survey, according to which } \\
\text { transfusion triggers vary significantly among } \\
\text { different clinicians, hospitals and countries [56]. } \\
\text { Systematic review on transfusion drivers in } \\
\text { orthopedic surgery shows low Hb and old } \\
\text { age to be the main predictors for the need of } \\
\text { transfusion, followed by surgical complexity, } \\
\text { low body weight, additional comorbidities }\end{array}$ & $\begin{array}{l}\text { A study on fast-track TJA predictors of LOS } \\
\text { and patient satisfaction found: } \\
\text { The need for blood transfusion to be the } \\
\text { main predictor of a longer stay ( }>3 \text { days) } \\
\text { Blood transfusion to occur in } 22 \% \text { and } 12 \% \text { of } \\
\text { THA and TKA respectively, although it does } \\
\text { not compromise a high satisfaction rank ( } 9.4 \\
\text { and } 9.3 \text { up to 10) } \\
\text { Transfusions were administered when } \\
\text { postoperative hematocrit level (at the first } \\
\text { day) was } 25 \% \text { less than preoperative. } \\
\text { Transfusions were associated with age, lack of } \\
\text { mobility during the first day after surgery, co- } \\
\text { morbidities, low Hb and increased ASA score [15]. } \\
\text { The need for blood transfusion is a predictor } \\
\text { that produces significant value in accelerated } \\
\text { pathways such as fast-track surgery, since they } \\
\text { provide caregivers with useful information to } \\
\text { plan for treatments and beds. } \\
\text { Waiting for blood transfusion is indeed one of } \\
\text { the main reasons to delay discharge [61, 62]. (*) }\end{array}$ \\
\hline
\end{tabular}

Erythropoietin (EPO)

Preoperative autologous blood donation (PAD) (rheumatoid arthritis, history of anemia,

diabetes, cardiovascular disease, renal failure, or metastasis), and female sex [57].

Studies on restrictive triggers in major orthopedic patients show transfusion rate and deep wound infections to be respectively reduced from 34 to $17 \%$, and from 2.6 to $1.5 \%$ [58].

This is confirmed by a prospective study on unilateral knee arthroplasty (UKA), which adopted a postoperative trigger $<8.5 \mathrm{~g} / \mathrm{dL}$ (or greater in case of a symptomatic patient): transfusion rates were reduced from 31 to $11.9 \%$, blood waste from 60 to $1 \%$, with no adverse outcomes [59].

Current evidence confirms that a restrictive trigger $(\mathrm{Hb}<8 \mathrm{~g} / \mathrm{dL})$ is safe and cheaper ${ }^{3}$ ... which is supported by the National Institute for Health and Clinical Excellence even more restrictive recommendations [60].

EPO reduces post-operative transfusions [63] both in THA and TKA [64-67], even in rheumatoid arthritis patients [67], but it is associated with adverse events such as deep venous thrombosis (DVT), pulmonary embolism (PE), fever, hypokalemia, urinary tract infection, nausea, hypoxia, and vomiting in up to $5 \%$ of the population [68-70].

Moreover, it is unclear whether benefits are not offset by costs [71].

Therefore, EPO is suggested in exceptional conditions such as patients with strong anemia who (i) cannot receive blood because of red cell antibodies, (ii) refuse donation because of religious beliefs $[18,60,72]$.

Major concerns regarding PAD are related to handling errors, blood infection, and poor cost-effectiveness [76-79].

The overall benefits of PAD in primary joint arthroplasty can outweigh the harms in alloimmune and rare blood types patients $[8,80]$.
The use of TXA has almost eliminated the need for other blood conservation strategies $[73,74]$, and is therefore a valuable innovation to be applied under a fast-track pathway [75].

The use of TXA has almost eliminated the need for other blood conservation strategies $[73,74]$, included PAD, which makes it a valuable innovation under a fast-track pathway[75]. 
Table 3 Intraoperative blood management

\begin{tabular}{|c|c|c|}
\hline Content & Conventional studies, guide lines, and recommendations & Fast-track setting \\
\hline $\begin{array}{l}\text { Minimally invasive surgery } \\
\text { (with or without navigation) }\end{array}$ & $\begin{array}{l}\text { MIS techniques are believed to reduce blood loss in } \\
\text { TJA procedures, included the so-called tissue sparing } \\
\text { surgery [81-85]. } \\
\text { Blood loss after minimally invasive TKA was compared } \\
\text { between using or not imageless navigation, together } \\
\text { with intraoperative tourniquet but no postoperative } \\
\text { drainage. }\end{array}$ & $\begin{array}{l}\text { Blood loss reduction is included in the benefits of MIS } \\
\text { TJA surgery. } \\
\text { However, a survey on fast-track TJA procedures } \\
\text { concludes that MIS benefits on blood loss are still } \\
\text { unclear [87], and more studies should be conducted to } \\
\text { assess whether its use in fast-track THA affects overall } \\
\text { patient satisfaction [88] }\left(^{*}\right) \text {. }\end{array}$ \\
\hline
\end{tabular}

Tourniquet

Anesthesia

Hypotensive epidural anesthesia (HEA)
Blood loss was not significantly affected by the use of imageless navigation, following which time of surgery was a bit longer but $\mathrm{Hb}$ reduction and amount of blood were similar [86].

Although the majority of orthopedic surgeons still widely use it, its role remains controversial.

If tourniquet reduces intraoperative blood loss, this gain can be offset by the amount of blood lost after its release [89].

A meta-analysis on 30 RCTs seems to confirm its lack of effectiveness in TKA for better clinical outcomes, less complications and better early post-operative ROM achieved without a tourniquet [90].

In order to provide guidelines for fast-track TKA, it was conducted a survey on anaesthetic techniques [94]. With regard to blood management, it was found that blood loss is not affected by administering regional (RA) or general anesthesia (GA), while RA is associated with other outcomes such as reduced post-operative pain, length of stay and better rehabilitation [95]. RA is associated with lower thromboembolic complications, even if-after performing a subgroup analysis - anticoagulants were the precaution who made the difference [96].

RA is suggested for TKA patients with comorbidities [97], while there is no evidence enough about their benefits on cardiovascular morbidity, DVT, and PE in association with pharmacological thromboprophylaxis [95].

In case of THK, the same authors did not find evidence enough to compare the benefits of GA or RA on blood loss [98], while others found RA to be better after adjusting for patients' specific comorbidities and/or when combined with accurate transfusion prevention $[99,100]$.

HEA was developed to combine the advantages of epidural anesthesia (airway problems, reduced rate of DVT) with the benefits of induced hypotension [102]. Although HEA's use seems to be safe and effective, it's
The benefits of tourniquet in TKA are also questioned in fast-track surgery.

An RCT found knee-extension $48 \mathrm{~h}$ after surgery to be reduced in 90\% patients regardless to its use. Moreover, tourniquet reduced bleeding during surgery, but had no benefits on postoperative Hb levels, pain, nausea, OS, or periarticular swelling. Finally, using or not a tourniquet had no difference in early postoperative outcomes after surgery [91]. A study on 151 fast-track TKA verified the effectiveness of a tourniquet on post-operative bleeding and rehabilitation together with suction drainage application.

Suction drain was associated to lower Hb levels, higher transfusion rate, higher pain and slower functional recovery, while short-term tourniquet did not influence postoperative bleeding and rehabilitation program [92]. (*) However, a protocol for another RCT aims to verify the effectiveness of a tourniquet on patient's recovery after fast-track TKA, in association to the anaesthetic regimen.

Primary outcome is cumulative intravenous oxycodone consumption by patient-controlled analgesia during the first 24 postoperative hours.

Secondary outcomes include postoperative nausea and vomiting, the length of hospital stay, the duration of the surgery, blood loss, demand for surgical unit resources, complications, readmissions, postoperative knee function, range of motion, health-related quality of life, prolonged pain, and mortality [93].

With regard to intraoperative blood loss, no difference was found in performing GA (through propofol and remifentanil) or spinal anesthesia (SA) (through intrathecal bupivacaine)

However, GA is confirmed to dominate on SA on relevant outcomes for a fast-track pathway, such as early mobilization, less opioid consumption, and reduced pain scores $6 \mathrm{~h}$ after surgery [101].

There seems to be no reason to choose or not for HEA

according to the pathway.

Searching the literature for \#hipothensive 
Table 3 Intraoperative blood management (Continued)

\begin{tabular}{ll}
\hline Content & Conventional studies, guide lines, and recommendations \\
\hline & not a first line method in TKA, while it is more spread \\
in THA [103-105].
\end{tabular}

Antifibrinolytic agents

Topical fibrin sealants (TFS)

(Intraoperative) cell salvage

Peri/intra-articular injections
The most common antifibrinolytic agents in use are Tranexamic Acid (TXA) and $\varepsilon$-aminocaproic acid (EACA) [106-108].

TXA is more cost-effective than EACA on reducing perioperative bleeding and transfusions [109]. Apoproptine is more effective at decreasing blood loss, but increase the risk of cardiovascular complications. Therefore, it has been removed from the market [110-112].

TXA seems therefore to be the best solution. Indeed, meta-analysis show the use of TXA in TKA to be and effective and safe solution in reducing blood loss [113].

A RCT proved TXA to dominate on post-operative cell salvage both in primary THA and TKA [114], which is confirmed by several studies, even if the ideal regime remains controversial, and variates according to topical (intra-articular), general (intra-venous), and amount of administration [73, 74, 115-120].

Multiple intravenous boluses injections (pre-, intrapostoperatively) proved to dominate on a single intravenous dose [121], as well as a bolus of tranexamic acid followed by infusion was found to be more useful than a single dose in decreasing perioperative blood loss in patients undergoing hip surgeries: it reduced allogenic blood transfusions without increasing risk of thromboembolic events [122].

Intra-articular administration is a safe alternative for TKA patients at risk for intravenous administration [123]: moreover, one intra-articular administration is as effective as three doses regimen in preventing blood loss with no difference in thromboembolic complications [124, 125].

According to another study, mixing IV and IA

administration is better than administering them alone $[126,127]$

RCTs show the high effectiveness of TXA, both with tourniquet and without $[117,118]$.

Finally, there is no contraindication for its use in patients with a history of venous thromboembolism [128].

Tranexamic acid has been recognized as a valuable innovation under a bundled payment model [11] (*).

\section{A meta-analysis on TKA suggests the administration of intravenous TXA to dominate on TFS [135], whose effectiveness and cost-effectiveness are debatable $[136,137]$.}

A meta-analysis on 43 trials show perioperative (intraand post-) cell salvage to reduce blood loss in both THA and TKA [138].

However, the study points out how more recent trials show blood salvage benefit to be overwhelmed by more effective innovations [139-141].

\section{Topical hemostatic vasoconstriction}

Epinephrine is the agent of choice for its topical hemostatic vasoconstriction [142]. Injections of epinephrine together with bupivacaine just before wound closure reduced 32\% of drain output, but showed no significant reduction in transfusion rate [143].
Fast-track setting

epidural anaeshtesia, \#hea, \#arthroplasty

and \#fast(-)track gave

no results.

Fast-track TJA was soon declared to produce no more complications than conventional procedures, including thromboembolic episodes [129].

TXA is shown to reduce perioperative blood loss (and the following need for allogenic blood transfusion) also in accelerated recoveries and clinical pathways, without increasing the rate of thromboembolism

$[14,92,130,131] .\left(^{*}\right)$

Combined intra-articular (IA) and intravenous TXA reduced blood loss in 60 fast-track TKA patients [132]. Adding low-dose epinephrine to TXA on 100 fast-track THA patients did not reduce blood loss during surgery, but reduced it of $180 \mathrm{~mL}$ within $24 \mathrm{~h} \mathrm{[133].} \mathrm{(*)}$ Tranexamic acid is recognized as a valuable innovation under a fast-track THA pathway [75]. Its effectiveness in conventional TKA had also been largely demonstrated [114, 134], supporting it to be a valuable innovation in fast-track TKA too.
The eventual use of TFS in revision surgery makes them irrelevant for fast-track pathways, which are dedicated to primary intervention.

The use of TXA has almost eliminated the need for other blood conservation strategies [73, 74], included intraoperative blood salvation, and is therefore a valuable innovation to be applied under a fast-track pathway [75].

Intraoperative cell salvage is still useful to those patients who cannot be administered TXA.

A synthesis on fast-track TJA clinical and organizational aspects questioned the value of adding epinephrine during anesthesia [129].

Adding epinephrine to TXA on 100 fast-track THA patients did not reduce intraoperative blood loss, but reduced it of $180 \mathrm{~mL}$ within $24 \mathrm{~h}$ [133] (*), confirming 
Table 3 Intraoperative blood management (Continued)

\begin{tabular}{|c|c|c|}
\hline Content & Conventional studies, guide lines, and recommendations & Fast-track setting \\
\hline & $\begin{array}{l}\text { Moreover, a recent study denies the effective } \\
\text { hemostatic role of intra-articular epinephrine } \\
\text { in TKA [144]. } \\
\text { However, the combined administration of low-dose } \\
\text { epinephrine and tranexamic acid reduced perioperative } \\
\text { blood loss and inflammatory response compared with } \\
\text { tranexamic acid alone, with no apparent increase in } \\
\text { thromboembolic and other complications [145]. }\end{array}$ & $\begin{array}{l}\text { perioperative blood loss to be reduced by the } \\
\text { combination between intravenous low-dose } \\
\text { epinephrine and tranexamic acid. }\end{array}$ \\
\hline & Local infiltration analgesia (LIA) & \\
\hline & $\begin{array}{l}\text { A review over } 11 \text { RCTS shows LIA to be a safe and } \\
\text { efficient technique for TJA [146]. } \\
\text { A systematic review over } 27 \text { RCTs confirmed LIA to } \\
\text { provide effective analgesia in TKA, either combined or } \\
\text { not with multimodal systemic analgesia; in contrast, LIA } \\
\text { provided limited additional benefit in THA when } \\
\text { combined with a multimodal regimen [147]. } \\
\text { The introduction of intraoperative LIA is consistent with } \\
\text { blood management for its combination with TXA } \\
\text { proved significant benefits on postoperative Hb levels, } \\
\text { reduced LOS, no increase in transfusion and, therefore, } \\
\text { better cost-effectiveness (when compared to } \\
\text { perioperative autologous blood salvage and } \\
\text { preoperative EPO) [148]. }\end{array}$ & $\begin{array}{l}\text { Postoperative pain treatment is a fundamental step in } \\
\text { achieving early rehabilitation and reduced hospital LOS, } \\
\text { therefore the use of LIA is ideal in fast-track pathways } \\
{[147](*) \text {, even more in combination with TXA, whose }} \\
\text { benefits were discussed in the dedicated section. }\end{array}$ \\
\hline $\begin{array}{l}\text { Bipolar and monopolar } \\
\text { sealants }\end{array}$ & $\begin{array}{l}\text { Bipolar sealant is a novel approach in TKA, but it } \\
\text { provides no significant difference in postoperative drain } \\
\text { output, } \mathrm{Hb} \text { level and transfusion requirement when } \\
\text { compared to monopolar sealant [149-155]. } \\
\text { As long as the cost-effectiveness of bipolar sealants } \\
\text { remains controversial, there is no reason to } \\
\text { adopt them in routine care [156]. }\end{array}$ & $\begin{array}{l}\text { A synthesis on fast-track TJA clinical and organizational } \\
\text { aspects included bipolar sealants as a means to } \\
\text { minimize blood loss and transfusions [129]. } \\
\text { However, there seems to be no particular reason to } \\
\text { choose or not for bipolar or monopolar sealants } \\
\text { according to the pathway. } \\
\text { Searching the literature for \#bipolar sealant, } \\
\text { \#monopolar sealant and \#fast(-)track gave no results. }\end{array}$ \\
\hline Platelet-rich plasma (PRP) & $\begin{array}{l}\text { Intra-operative adoption of PRP is shown to reduce } \\
\text { TKA post-operative blood loss [157]. } \\
\text { PRP is effective in wound healing, but controversial in } \\
\text { haemostasis }[158,159] \text {. }\end{array}$ & $\begin{array}{l}\text { There seems to be no reason to choose or not for PRP } \\
\text { according to the pathway. } \\
\text { Searching the literature for \#platelet rich plasma, \#PRP, } \\
\text { \#blood and \#fast(-)track gave no results. }\end{array}$ \\
\hline Bone wax & $\begin{array}{l}\text { Bone wax helps to control bleeding from bone surface } \\
\text { during surgical procedures [160]. } \\
\text { Despite its recent use in TKA to reduce total blood loss } \\
\text { while maintaining higher Hb levels, more studies are } \\
\text { needed to verify its safety with regard to allergic } \\
\text { reactions, inflammation and foreign bodies formation } \\
{[161,162] \text {. }}\end{array}$ & $\begin{array}{l}\text { There seems to be no reason to choose or not for } \\
\text { bone wax according to the pathway. } \\
\text { Searching the literature for \#bone wax, \#arthroplasty, } \\
\text { \#orthopedics and \#fast(-)track gave no results. }\end{array}$ \\
\hline Sealing femoral tunnel & $\begin{array}{l}\text { A meta-analysis over } 4 \text { TKA RCTs concludes that the } \\
\text { use of extramedullary (EM) guide results in less blood } \\
\text { loss-given similar operation time-in comparison } \\
\text { with the intramedullary (IM) one [163]. However, } \\
\text { IM seems to dominate EM on TKA } \\
\text { survivorship [164]. }\end{array}$ & $\begin{array}{l}\text { There seems to be no reason to choose or not for } \\
\text { sealing femoral tunnel according to the pathway. } \\
\text { Searching the literature for \#sealing femoral tunnel, \# } \\
\text { arthroplasty and \#fast(-)track gave no results. }\end{array}$ \\
\hline
\end{tabular}

had been established when postoperative hematocrit level at the first day is $25 \%$ less than preoperative, while more recent studies found preoperative iron supplement to be a cost-effective solution for non-anemic THA patients. However, fast-track procedures are becoming more and more inclusive, provided that a multidisciplinary management of risk factors is implemented. TKA patients aged $\geq 65$ show a weak but significant association between postoperative $\mathrm{Hb}$ and 6-min walk test early after surgery, but not with other functional criteria nor quality of life. Postoperative anemia, blood transfusions, and lack of mobilization are the main medical causes of delayed discharge (27.3 more than 4 days) for THA patients aged $\geq 85$, while preoperative anemia is the main medical cause of readmission of the same population within 90 days after the intervention, together with suspected (but disproved) thromboembolic events. Finally, stroke is a recognised event which can occur after both TKA and THA procedures: it is therefore fundamental to check for preoperative anticoagulants to avoid cardiovascular perioperative complications in elderly patients. If these precautions prove successful, fast-track pathways realize the possibility of including older patients in major joint replacement programs [202]. 
Table 4 Postoperative blood management

\begin{tabular}{|c|c|c|}
\hline Content & Conventional studies, guide lines, and recommendations & Fast-track setting \\
\hline Postoperative anemia & See Table 2. & \\
\hline Compression & $\begin{array}{l}\text { Inelastic compression bandage after TKA seems not to } \\
\text { reduce blood loss, but offers a slight improvement in } \\
\text { reducing postoperative pain and early functional } \\
\text { outcomes [167, 168]. } \\
\text { According to other studies, there is no difference in } \\
\text { compression method [169-171]. }\end{array}$ & $\begin{array}{l}\text { Intermittent pneumatic compression to reduce } \\
\text { bleeding in (fast-track) high risk patients is } \\
\text { considered later, together with thromboprophylaxis. }\end{array}$ \\
\hline Cryotherapy & $\begin{array}{l}\text { Systematic review on } 13 \text { RCTs proved cryotherapy to be } \\
\text { effective in reducing blood loss after TKA selected patients, } \\
\text { while its benefits remained controversial after THA [172]. } \\
\text { Previous systematic review and meta-analysis over } 11 \text { TKA } \\
\text { studies show only slight short-lasting benefit of } \\
\text { cryotherapy in routine procedures [173]. }\end{array}$ & $\begin{array}{l}\text { Cryotherapy has been advocated as a safe and effective } \\
\text { strategy to improve fast-track TKA postoperative results, } \\
\text { acting on pain, edema, and blood loss. } \\
\text { Continuous cold flow device in the acute postoperative } \\
\text { setting did not show superiority in comparison with } \\
\text { traditional icing regimen. } \\
\text { Thus, due to the costs, it should be reserved to selected } \\
\text { cases [174]. }\end{array}$ \\
\hline Limb position & $\begin{array}{l}\text { Different knee flexion positions (e.g., hip elevation by } 60^{\circ} \\
\text { combined with } 60^{\circ} \text { knee flexion) have been reported to } \\
\text { have promising results with respect to reducing } \\
\text { perioperative blood loss [175-177]. } \\
\text { Postoperative knee flexion is therefore an easy, } \\
\text { inexpensive, and effective method in blood loss } \\
\text { reduction [18]. }\end{array}$ & $\begin{array}{l}\text { There seems to be no reason to opt for a limb position } \\
\text { according to the pathway. } \\
\text { Searching the literature for \#limb(-)position, \#blood and } \\
\text { \#fast(-)track gave } 2 \text { results, none of which consistent with } \\
\text { orthopedics. }\end{array}$ \\
\hline Postoperative cell savage & $\begin{array}{l}\text { PCS effectiveness and cost-effectiveness seem to be } \\
\text { maximized in patients with pre-operative } \mathrm{Hb} 12-15 \mathrm{~g} / \mathrm{dL} \text {, } \\
\text { while in patients with pre-operative Hb less than } 12 \mathrm{~g} / \mathrm{dL} \\
\text { it should be combined with other techniques [178]. }\end{array}$ & $\begin{array}{l}\text { The use of TXA has almost eliminated the need for other } \\
\text { blood conservation strategies [73, 74], included } \\
\text { postoperative blood salvation, and is therefore a valuable } \\
\text { innovation to be applied under a fast-track pathway [75]. } \\
\text { Postoperative cell salvage is still useful to those patients } \\
\text { who cannot be administered TXA. }\end{array}$ \\
\hline $\begin{array}{l}\text { Drainage clamping } \\
\text { and removal }\end{array}$ & $\begin{array}{l}\text { The introduction of drainage clamping in bilateral total } \\
\text { joint arthroplasty proved effective and cost-effective in } \\
\text { pioneer studies on TKA and THA [179, 180]. } \\
\text { More recent studies on TKA proved its effectiveness to be } \\
\text { debatable [181-183], and when effective, proved } \\
\text { debatable intervals of administration [184-186]. } \\
\text { Today, 3-h interval clamping proved effective in reducing } \\
\text { TKA postoperative Hb drop with no increase in } \\
\text { thromboembolic episodes and wound complications } \\
\text { [187], and proved to be even more effective in } \\
\text { combination with TXA, even if there is still need } \\
\text { of a major focus on duration and intervals [188, 189]. } \\
\text { With regard to THA, 4-h drainage clamping proved } \\
\text { potential for routine implementation, for it reduced blood } \\
\text { loss and the following need of transfusion with no } \\
\text { significant difference on other clinical outcomes [190]. } \\
\text { According to a RCT on } 224 \text { THA patients, intra-articular } \\
\text { soaking of high concentration of TXA with 2-h clamping } \\
\text { drainage can reduce the total blood loss and transfusion } \\
\text { rates in primary THA without significant increase in } \\
\text { postoperative thrombotic complications [191]. }\end{array}$ & $\begin{array}{l}\text { A prospective cohort study evaluated the safety and } \\
\text { feasibility of early removal of drainage tube in primary fast- } \\
\text { track TKA. } \\
\text { Wound drainage was removed within } 6-12 \mathrm{~h} \text { after surgery. } \\
\text { The procedure could drain the haematocele and reduce } \\
\text { the risk of infection, without increasing the sense of pain, } \\
\text { inflammatory reaction, limb swelling, and total blood loss. } \\
\text { Removal of drainage tube was therefore safe and feasible } \\
\text { within } 6-12 \mathrm{~h} \text { after surgery [192]. } \\
\text { According to clinical expertise, drains can be avoided in } \\
\text { selected cases, when local conditions free of obvious } \\
\text { bleeding following re-established pressure ensure the } \\
\text { absence of the risk of hematoma. }\end{array}$ \\
\hline
\end{tabular}

Intraoperatively, tranexamic acid is probably the simplest, safe and cost-effective innovation also in case of fast-track procedures, for it almost eliminated the need for other blood conservation strategies. Its benefits increase when combined (i) with local infiltration analgesia, both in hip and knee replacement, as it produces a significant reduction in postoperative $\mathrm{Hb}$ levels, pain and length of stay, together with better rehabilitation outcomes; (ii) with low-dose epinephrine in THA, producing a reduction of $180 \mathrm{~mL}$ blood loss within $24 \mathrm{~h}$ after surgery. The benefits of minimally invasive surgery on blood loss are still debated, and more studies are needed to evaluate its impact on patient satisfaction in fast-track TJA. With regard to TKA, the use of a tourniquet reduces bleeding during surgery, but produces no benefit on knee extension, postoperative $\mathrm{Hb}$ levels, pain, and nausea; studies are evaluating its use in combination with multimodal anaesthetic and analgesic regimens. General anesthesia is equivalent to spinal anesthesia with regard to blood loss, but the former dominates the second on several other outcomes, including early 
Table 5 Mechanical and chemical thromboprophylaxis in 632 primary TJA patients

Is the incidence of readmissions resulting from VTE and bleeding complications higher with LMWH or with mobile compression plus ASA?

Is the incidence of wound bleeding complications higher with LMWHG or with mobile compression plus ASA?

In TKA, is the frequency of systemic bleeding events and complications related to chemoprophylaxis higher with $\mathrm{LMWH}$ or with mechanical compression plus ASA?

Is there a difference in symptomatic VTEs between LMWH and mechanical compression plus ASA?
In THA, there was no difference in the frequency or readmissions for bleeding complication (wound or systemic) between the treatments.

In TKA, patients treated with $\mathrm{LMWH}$ had higher readmission rates within 6 weeks after surgery, because of bleeding complications, wound infection, or VTE.

In THA, there was higher wound bleeding complication frequency with $\mathrm{LMWH}$.

In TKA, patients treated with LMWH had a higher frequency of wound bleeding complications or infection.

Patients treated with LMWH had higher rates of systemic bleeding or complications.

There was no difference between the rate of symptomatic VTEs between the groups. mobilization, amount of opioid consumption, and pain scores $6 \mathrm{~h}$ after surgery.

Postoperative thromboprophylaxis is the step which has received greater focus. The European Guidelines on VTE prevention suggest different combinations according to patient characteristics and procedures, underlining the benefits of early mobilization together with mobile mechanical compression and pharmacological treatment. Traditional icing provides a high costeffective benefit on several postoperative outcomes, such as pain, edema, and blood loss, reserving more complicate cryotherapy devices only to selected patients. Finally, removal of drains is safe and feasible within 6-12 $h$ after TKA, although clinical experts question their usefulness.

Several strategies and treatments such as hypotensive epidural anesthesia, topical fibrin sealants, platelet-rich plasma, sealing femoral tunnel, and limb position shows no variation between conventional or fast-track procedures.

A methodological limitation of the study is its partial reproducibility, as the fast-track information achieved from the first electronic search is integrated with information from further searches, previous knowledge, article references, or clinical tips. This is also why the study may not be exhaustive. However, this methodological

Table 6 VTE prevention in fast-track and day-surgery orthopedic procedures

\begin{tabular}{lll}
\hline & Low VTE risk procedure & $\begin{array}{l}\text { High VTE risk } \\
\text { procedure }\end{array}$ \\
\hline $\begin{array}{ll}\text { Low VTE risk } \\
\text { patient }\end{array}$ & $\begin{array}{l}\text { GT } \\
\text { PT only in case they have to } \\
\end{array}$ & GT + PT (LMWH/ \\
& two das) and/or MT \\
High VTE risk & GT + PT (LMWH/AAS) & \\
patient & and/or MT & GT + PT \\
$\begin{array}{l}\text { General thromboprophylaxis (GT), early ambulation, optimal hydration, } \\
\text { pharmacological thromboprophylaxis (PT), low molecular weight heparin } \\
\text { (LMWH) and/or aspirin (AAS), mechanical thromboprophylaxis (MT), } \\
\text { intermittent pneumatic compression for high-risk of bleeding }\end{array}$
\end{tabular}

limitation likely compensates for the lack of information and systematic approach on several topics in this field.

\section{Conclusion}

Many blood management strategies have been put forward to support safe and cheaper orthopedic elective TJA procedures. This article provides a roadmap to more uniform blood management in fast-track orthopedic pathways, pointing out current evidence as well as suggestions for further research.

The difference between conventional and fast-track pathways does not lie in the issues of blood management, which are related to surgical procedures, materials and patients, but in the way in which these contents are integrated with each other, since elective orthopedic procedures offer significant room for planning.

The more fast-track clinical studies are able to add evidence, the greater the benefits for patients, providers, and funders. The next step, therefore, is to put theory into practice [203].

\section{Acknowledgements \\ Not applicable.}

\section{Authors' contributions}

$\mathrm{GB}, \mathrm{FN}$, and PP contributed to the design of the work. FP contributed to the acquisition and analysis. PS contributed to the interpretation of data. NM and GP developed the idea, supervised the writing of and revision of the manuscript. All authors read and approved the final manuscript.

\section{Funding}

Not applicable.

\section{Availability of data and materials}

Not applicable.

Ethics approval and consent to participate

Not applicable.

Consent for publication

Not applicable.

Competing interests

The authors declare that they have no competing interests. 


\section{Author details}

${ }^{1}$ IRCCS Orthopedic Institute Galeazzi, Scientific Direction, Milan, Italy. ${ }^{2}$ Department of Musculoskeletal Disorders, School of Medicine and Surgery, University of Salerno, Fisciano, Italy. ${ }^{3}$ San Giovanni di Dio e Ruggi D'Aragona Hospital "Clinica Orthopedica" Department, Hospital of Salerno, Salerno, Italy. ${ }^{4}$ Queen Mary University of London, Barts and the London School of Medicine and Dentistry, Centre for Sports and Exercise Medicine, London, England. ${ }^{5}$ Vita-Salute San Raffaele University, Scientific Direction, Milan, Italy. ${ }^{6}$ University of Milan, Department of Biomedical Sciences for Health, Milan, Italy.

Received: 9 June 2019 Accepted: 25 July 2019

Published online: 20 August 2019

\section{References}

1. Jasper $\mathrm{LL}$, Jones $C A$, Mollins J, Pohar SL, Beaupre LA. Risk factors for revision of total knee arthroplasty: a scoping review. BMC Musculoskeletal Disord. 2016;17:182.

2. Kurtz S, Ong K, Lau E, Mowat F, Halpern M. Projections of primary and revision hip and knee arthroplasty in the United States from 2005 to 2030. J Bone Joint Surg. Am. 2007:89:780-5.

3. Ponnusamy KE, Kim TJ, Khanuja HS. Perioperative blood transfusions in orthopaedic surgery. J Bone Joint Surg Am. 2014;96:1836-44.

4. Kopolovic I, Ostro J, Tsubota H, Lin Y, Cserti-Gazdewich CM, Messner HA, Keir AK, DenHollander N, Dzik WS, Callum J. A systematic review of transfusion-associated graft-versus-host disease. Blood. 2015;126: 406-14.

5. Dwyre D, Fernando LP, Holland PV. Hepatitis B, hepatitis C and HIV transfusion-transmitted infections in the 21st century. Vox Sang. 2011; 100:92-8.

6. Perkins HA, Busch MP. Transfusion-associated infections: 50 years of relentless challenges and remarkable progress. Transfusions. 2010;50: 2080-99.

7. Bierbaum BE, Callaghan JJ, Galante JO, Rubash HE, Tooms RE, Welch RB. An analysis of blood management in patients having a total hip or knee arthroplasty. J Bone Join Surg Am. 1999;81:2-10.

8. Moonen AFCM, Neal TD, Pilot P. Peri-operative blood management in elective orthopaedic surgery. A critical review of the literature. Injury. 2006; 37(Suppl 5):S11-6.

9. Song JH, Park JW, Lee YK, Kim IS, Nho JH, Lee KJ, Park KK, Kim Y, Park $\mathrm{JH}$, Han SB. Management of Blood Loss in Hip Arthroplasty: Korean Hip Society Current Consensus. Hip Pelvis. 2017;29:81-90.

10. Porter ME, Teisberg EO. Redefining Competition in Health Care. Harv Bus Rev. 2004;82:64-76.

11. Kansagra A, Andrzejewski C, Krushell R, Lehman A, Greenbaum J, Visintainer P, McGirr J, Mahoney K, Cloutier D, Ehresman A, Stefan MS. Blood management strategies to reduce transfusions after elective lower-extremity joint arthroplasty surgeries: one tertiary care hospital's early experience with an alternative payment model-a total joint "Bundle". Am J Med Qual. 2017;32:668-74.

12. Kim K, lorio R. The 5 Clinical Pillars of Value for Total joint arthroplasty in a bundled payment paradigm. J Arthroplasty. 2017;32:1712-6.

13. Benedetti MG, Sarti D, Bonfiglioli Stagni S, Mariani E. Setting, clinical pathways, fast-track and rehabilitation following knee arthroplasty: a literature review. Open Rehabil J. 2015;8:17-24.

14. Stowers MD, Lemanu DP, Coleman B, Hill AG, Munro JT. Review article: Perioperative care in enhanced recovery for total hip and knee arthroplasty. J Orthop Surg (Hong Kong). 2014;22:383-92.

15. Husted H, Holm G, Jacobsen S. Predictors of length of stay and patient satisfaction after hip and knee replacement surgery: fast-track experience in 712 patients. Acta Orthop. 2008;79:168-73.

16. Pitter FT, Jørgensen CC, Lindberg-Larsen M, Kehlet $H$. Lundbeck Foundation Center for fast-track hip and knee replacement collaborative group. Anesth Analg. 2016;122:1807-15.

17. Lovecchio F, Alvi H, Sahota S, Beal M, Manning D. Is Outpatient arthroplasty as safe as fast-track inpatient arthroplasty? A propensity score matched analysis. J Arthroplasty. 2016;31:197-201.

18. Tzatzairis T, Vogiatzaki T, Kazakos K, Drosos IG. Perioperative blood management strategies for patients undergoing total knee replacement: Where do we stand now? World J Orthop. 2017;8:441-54.
19. Holt JB, Miller BJ, Callaghan JJ, Clark CR, Willeborg MD, Noiseux NO. Minimizing blood transfusion in total hip and knee arthroplasty: a muldimodal approach. J Arthroplasty. 2016;31:378-82.

20. Cherian JJ, Kapadia BH, Issa K, Banerjee S, Mclnerney VK, Harwin SF, Mont MA. Preoperative blood management strategies for total hip arthroplasty. Surg Technol Int. 2013;23:261-6.

21. Zhang S, Huang Q, Xu B, Ma J, Cao G, Pei F. Effectiveness and safety of an optimized blood management program in total hip and knee arthroplasty. Medicine (Baltimore). 2018;97:e9429.

22. Venclauskas $L$, Jenny JY, Kiaersgaard-Andersen $P$, Jans $\varnothing$. ESA VTE guidelines task force. Eur J Anaesthesiol. 2018;35:134-8.

23. Kamath AF, Pagnano MW. Blood management for patients undergoing total joint arthroplasty. JBJS Rev. 2013:1.

24. Liumbruno GM, Bennardello F, Lattanzio A, Piccoli P, Rossetti G, Italian Society of Transfusion Medicine and Immunohaematology (SIMTI) Working Party. Recommendations for the transfusion management of patients in the peri-operative period. I. The pre-operative period. Blood Transfus. 2011a;9: 19-40.

25. Liumbruno GM, Bennardello F, Lattanzio A, Piccoli P, Rossetti G, Italian Society of Transfusion Medicine and Immunohaematology (SIMTI) Working Party. Recommendations for the transfusion management of patients in the peri-operative period. II. The intra-operative period. Blood Transfus. 2011 b;9: 189-217.

26. Liumbruno GM, Bennardello F, Lattanzio A, Piccoli P, Rossetti G, Italian Society of Transfusion Medicine and Immunohaematology (SIMTI) Working Party. Recommendations for the transfusion management of patients in the peri-operative period. III. The pre-operative period. Blood Transfus. 2011c;9: 320-35

27. Centro Cochrane Italiano. (n.d.)Available from: https://www.cochrane.it/sites/ cochrane.it/files/public/uploads/guidausorevisioni.pdf. Accessed 10 June 2019.

28. Vaglio S, Prisco D, Biancofiore G, Rafanelli D, Antonioli P, Lisanti M, Andreani L, Basso L, Velati C, Grazzini G, Liumbruno GM. Recommendations for the implementation of a patient blood management programme. Application to elective major orthopaedic surgery in adults. Blood transfus. 2016;14:23-65.

29. Goodnough LT, Maniatis A, Earnshaw P, Benoni G, Beris P, Bisbe E, Fergusson DA, Gombotz H, Habler O, Monk TG, Ozier Y, Slappendel R, Szapalski M. Detection, evaluation, and management of preoperative anaemia in the elective orthopaedic surgical patient: NATA guidelines. $\mathrm{Br} \mathrm{J}$ Anaesthes. 2011;106:13-22.

30. McLean E, Cogswell E, Egli I, Wojdyla D, de Benoist B. Worldwide prevalence of anaemia, WHO vitamin and Mineral Nutrition Information System, 19932005. Public Health Nutr. 2009;12:444-54.

31. Muňoz M, Gomez-Ramirez S, Kozek-Langener S, Shander A, Richards T, Pavía J, Kehlet H, Acheson AG, Evans C, Raobaikady R, Javidroozi M, Auerbach M. "Fit to fly": overcoming barriers to preoperative haemoglobin optimization in surgical patients. Br J Anaesth. 2015;115:15-24.

32. Theusinger OM, Kind SL, Seifert B, Borgeat L, Gerber C, Spahn DR. Patient blood management in orthopaedic surgery: a four-year follow-up of transfusion requirements and blood loss from 2008 to 2011 at the Balgrist University Hospital in Zurich, Switzerland. Blood Transfus. 2014;12:195-203.

33. Rogers BA, Cowie A, Alcock C, Rosson JW. Identification and treatment of anaemia in patients awaiting hip replacement. Ann R Coll Surg Engl. 2008; 90:504-7.

34. Rosencher N, Poisson D, Albi A, Aperce M, Barré J, Samama CM. Two injections of erythropoietin correct moderate anemia in most patients awaiting orthopedic surgery. Can J Anaesth. 2005;52:160.5.

35. Husted $\mathrm{H}$, Holm G. Fast track in total hip and knee arthroplasty - experiences from Hvidovre University Hospital, Denmark. Injury. 2006:37:S31-5.

36. Jans $\varnothing$, Jørgensen C, Kehlet $H$, Johansson PI. Lundbeck Foundation Centre for Fast-track Hip and Knee Replacement Collaborative Group. Transfusion. 2014;54:717-26.

37. Jans $\varnothing$, Bandholm T, Kurbegovic S, Solgaard S, Kjaersgaard-Andersen P, Johansson PI, Kehlet H. Lundbeck Foundation Centre for Fast-Track Hip and Knee Replacement Collaborative Group. Blood Management. 2016; 56:917-25.

38. Guralnik JM, Eisenstaedt RS, Ferrucci L, Klein HG, Woodman RC. Prevalence of anemia in persons 65 years and older in the United States: evidence for a high rate of unexplained anemia. Blood. 2004;104:2263-8.

39. Guyatt GH, Patterson C, Ali M, Singer J, Levine M, Turpie I, Meyer R. Diagnosis of iron-deficiency anemia in the elderly. Am J Med. 1990;88:205-9. 
40. Kopanidis P, Hardidge A, McNicol L, Tay S, McCall P, Weinberg L. Perioperative blood management programme reduces the use of blood allogenic transfusion in patients undergoing total hip and knee arthroplasty. J Orthop Surg Res. 2016;11:28.

41. Beris P, Muńoz M, García-Erce JA, Thomas D, Maniatis A, Van der Linden P. Perioperative anaemia management: consensus statement on the role of intravenous iron. Br J Anaesthesia. 2008:599-604.

42. Onken JE, Bregman DB, Harrington RA, Morris D, Acs P, Akright B, Barish C, Bhaskar BS, Smith-Nguyen NG, Butcher A, Koch TA, Goodnough LT. A multicenter, randomized, active-controlled study to investigate the efficacy and safety of intravenous ferric carboxymaltose in patients with iron deficiency anemia. Transfusion. 2014;54:306-15.

43. Halfdanarson TR, Litzow MR, Murray JA. Hematologic manifestations of celiac disease. Blood. 2007;109:412-21.

44. Muňoz M, García-Erce JA, Cuenca J, Bisbe E, Naveira E, AWGE (Spanish Amnaemia Working Group). On the role of iron therapy for reducing allogenic blood transfusion in orthopaedic surgery. Blood Transfus. 2012;10:8-22.

45. Jans $\varnothing$, Nielsen CS, Khan N, Gromov K, Troelsen A, Husted H. Iron deficiency and preoperative anaemia in patients scheduled for elective hip- and knee arthroplasty - an observational study. Vox Sang. 2018;113:260-7.

46. Scardino M, Di Matteo B, Martorelli F, Tanzi D, Kon E, D'Amato T. Improved patient blood management and cost saving in hip replacement surgery through the implementation of pre-operative Sucrosomial ${ }^{\circledR}$ iron supplementation: a quality improvement assessment study. Int Orthop. 2019;43:39-46.

47. Tendera M, Wojakowski W. Role of antiplatelet drugs in the prevention of cardiovascular events. Thromb Res. 2003;110:5-6.

48. Douketis JD, Spyropoulos AC, Spencer FA, Mayr M, Jaffer AK, Eckman MH, Dunn AS, Kunz R. Perioperative management of antithrombotic therapy: antithrombotic therapy and prevention of thrombosis, 9th ed: American College of Chest Physicians Evidence-Based Clinical Practice Guidelines. Chest. 2012;141:e326S-50S

49. Chassot PG, Delabays A, Spahn DR. Perioperative antiplatelet therapy: the case for continuing therapy in patients at risk of myocardial infarction. $\mathrm{Br}$ J Anaesthes. 2007;99:316-28.

50. Vandermeulen EP, Van Aken H, Vermylen J. Anticoagulants and spinalepidural anesthesia. Anesth Analg. 1994;79:1165-77.

51. Jørgensen CC, Kehlet H, Lundbeck Foundation centre for fast-track hip and knee replacement collaborative group. Time course and reasons for 90-day mortality in fast-track hip and knee arthroplasty. Acta Anaesthesiol Scand. 2017:61:436-44

52. Jørgensen CC, Petersen MA, Kehlet H. Lundbeck Foundation Centre for Fast-Track Hip and Knee Replacement Collaborative Group. BMJ Open. 2016; 6:e009813.

53. Petersen PB, Kehlet $H$, Jørgensen CC, Lundbeck foundation centre for fasttrack hip and knee replacement collaborative group. Safey of in-hospital only thromboprophylaxis after fast-track total hip and knee arthroplasty: a prospective follow-up study in 17.582 Procedures. Thromb Haemost. 2018; 118:2152-61.

54. Gombotz H, Rehak PH, Shander A, Hofmann A. Blood use in elective surgery: the Austrian benchmark study. Transfusion. 2007;47:1468-80.

55. Young SW, Marsh DJ, Akhavani MA, Walker CG, Skinner JA. Attitudes to blood transfusion post arthroplasty surgery in the United Kingdom: a national survey. Int Orthop. 2008;32:325-9.

56. Cobain TJ, Vamvakas EC, Wells A, Titlestad K. A survey of the demographics of blood use. Transfus Med. 2007;17:1-15.

57. Barr PJ, Donnelly M, Cardwell C, Alam SS, Morris K, Parker M, Bailie KE. Drivers of transfusion decision making and quality of the evidence in orthopedic surgery: a systematic review of the literature. Transfus Med Rev. 2011;25:304-16.

58. Slappendel R, Dirksen R, Weber EW, van der Schaaf DB. An algorithm to reduce allogenic red blood cell transfusions for major orthopedic surgery. Acta Orthop Scand. 2003;74:569-75.

59. Ballantyne A, Walmsley $\mathrm{P}$, Brenkel I. Reduction of blood transfusion rates in unilateral total knee arthroplasty by the introduction of a simple blood transfusion protocol. Knee. 2003;10:379-84.

60. National Institute for Health and Clinical Excellence (NICE). Blood transfusion guidelines. 2015. Available from: https://www.nice.org.uk/guidance/ng24/ chapter/Key-priorities-for-implementation. Accessed 10 June 2019.
61. Husted H, Lunn TH, Troelsen A, Gaarn-Larsen L, Kristensen BB, Kehlet H. Why still in hospital after fast-track hip and knee arthroplasty? Acta Orthop. 2011. 82:679-84.

62. Jans $\varnothing$, Kehlet J, Johansson PI. Blood transfusion in major orthopaedic surgery. Ugeskr Laeger. 2011;173:815-7.

63. Weber EW, Slappendel $R$, Hemon $Y$, Mähler $S$, Dalén $T$, Rouwet $E$, van Os J, Vosmaer A, van der Ark P. Effects of eopoetin alfa on blood transfusions and postoperative recovery in orthopaedic surgery: the European Epoetin Alfa Surgery Trial (EEST). Eur J Anaesthesiol. 2005;22: 249-57.

64. Goodnough LT, Monk TG. Erythropoietin therapy in the perioperative setting. Clin Orthop Related Res. 1998;357:82-8.

65. Faris PM, Ritter MA. Epoetin alfa. A bloodless approach for the treatment of perioperative anemia. Clin Orthop Relat Res. 1998;357:60-7.

66. De Andrade JR, Jove M, Landon G, Frei D, Guilfoyle M, Young DC. Baseline hemoglobin as a predictor of risk of transfusion and response to Epoetin alfa in orthopedic surgery patients. Am J Orthop (Belle Mead NJ). 1996;25: 533-42

67. Slappendel R, Weber EW, Hémon YJ, Mähler S, Dalén T, Rouwet EF, van Os JJ, Vosmaer A, van der Ark PD. Patients with and without rheumatoid arthritis benefit equally from preoperative epoetin-alpha treatment. Acta Orthop. 2006;77:677-83.

68. Keating EM, Callaghan JJ, Ranawat AS, Bhirangi K, Ranawat CS. A randomized, parallel-group, open-label trial of recombinant human erythropoietin vs preoperative autologous donation in primary total joint arthroplasty: effect of postoperative vigor and handgrip strength. J Arthroplasty. 2007;22:235-3.

69. Deutsch A, Spaulding J, Marcus RE. Preoperative epoetin alfa vs autologous blood donation in primary total knee arthroplasty. J Arthroplasty. 2006;21: 628-35.

70. Rosencher N, Poisson D, Albi A, Aperce M, Barré J, Samama CM. Two injections of eryhtopoietin correct moderate anemia in most patients awaiting orthopedic surgery. Can J Anaesth. 2005;52:160-5.

71. Bedair H, Yang J, Dwyer MK, McCarthy JC. Preoperative erythropoietin alpha reduces postoperative transfusions in THA and TKA but may not be costeffective. Clin Orthop Relat Res. 2015:473:590-6.

72. Vaislic CD, Dalibon N, Ponzio O, Ba M, Jugan E, Lagneau F, Abbas P, Olliver Y, Gaillard D, Baget F, Sportiche M, Chedid A, Chaoul G, Maribas P, Dupuy C, Robine B, Kasanin N, Michon H, Ruat JM, Habis M, Bouharaoua T. Outcomes in cardiac surgery in 500 consecutive Jehovah's Witness patients: 21 year experience. J Cardiothorac Surg. 2012;7:95.

73. Alshryda S, Sukeik M, Sarda P, Blenkinsopp J, Haddad FS, Mason JM. A systematic review and meta-analysis of the topical administration of tranexamic acid in total hip and knee replacement. Bone Joint J. 2014;96-B:1005-15.

74. Raveendran R, Wong J. Tranexamic acid: more evidence for its use in joint replacement surgery. Transfusion. 2014;54:2-3.

75. Zagra L. Advances in hip arthroplasty surgery: what is justified? EFORT Open Rev. 2017;2:171-8.

76. Goldman M, Rémy-Prince S, Trépanier A, Décary F. Autologous donation error rates in Canada. Transfusion. 1997;37:523-7.

77. Tretiak R, Laupacis A, Rivière M, McKerracher K, Souetre E. Cost of allogenic and autologous blood transfusion in Canada. Canadian Cost of Transfusion Study Group. CMAJ. 1996;154:1501-8.

78. Etchason J, Petz L, Keeler E, Calhoun L, Kleinman S, Snider C, Fink A, Brook $\mathrm{R}$. The cost effectiveness of preoperative autologous blood donations. $\mathrm{N}$ Engl J Med. 1995;332:719-24.

79. Birkmeyer JD, Goodnough LT, AuBuchon JP, Noordsij PG, Littenberg B. The cost-effectiveness of preoperative autologous blood donation for total hip and knee replacement. Transfusion. 1993;33:544-51.

80. Kozek-Langenecker SA, Afshari A, Albaladejo P, Santullano CA, De Robertis E, Filipescu DC, Fries D, Görlinger K, Haas T, Imberger G, Jacob M, Lancé M, Llau J, Mallett SS, Rahe-Meyer N, Samama CM, Smith A, Solomon C, Van der Linden P, Wikkelsø AJ, Wouters P, Wyffels P. Management of severe perioperative bleeding: guidelines from the European Society of Anaesthesiology. Eur J Anaesthesiol. 2013;30:270-382.

81. Confalonieri N, Manzotti A, Montironi F, Pullen C. Tissue sparing surgery in knee reconstruction: unicompartmental (UKA), patellofemoral (PFA), UKA + PFA, biunicompartmental (Bi-UKA) arthroplasties. J Orthop Traumatol. 2008:9:171-7.

82. Regis D, Residori A, Rossi N, Bartolozzi P. Tissue-sparing surgery in total hip arthroplasty: sensible approaches and tested evidence. J Orthopaed Traumatol. 2007:8:199-201. 
83. Huang HT, Su JY, Chang JK, Chen CH, Wang GJ. The early clinical outcomes of minimally invasive quadriceps-sparing total knee arthroplasty: report of a 2-year follow-up. J Arthroplasty. 2007;22:1007-12.

84. Matta JM, Shahrdar C, Ferguson T. Single-incision anterior approach for total hip arthroplasty on an orthopaedic table. Clin Orthop Related Res. 2005;441:115-24.

85. Light TR, Keggi KJ. Anterior approach to hip arthroplasty. Clin Orthop Related Res. 1980;152:255-60.

86. Chang CW, Wu PT, Yang CY. Blood loss after minimally invasive total knee arthroplasty: effects of imageless navigation. Kaohsiung J Med Sci. 2010;26: 237-43.

87. Lloyd JM, Wainwright T, Middleton RG. What is the role of minimally invasive surgery in a fast track hip and knee replacement? Ann R Coll Surg Engl. 2012;94:148-51.

88. Delanois RE, Gwam C, Mistry JB, Khlopas A, Chughtai M, Ramkumar P, Piuzzi N, Berger R, Bonutti PM, Malkani AL, Mont MA. Does Length of Stay Influence How Patients Rate Their Hospitalization After Total Hip Arthroplasty? Surg Technol Int. 2017;30:393-8.

89. Ejaz A, Laursen AC, Kappel A, Laursen MB, Jakobsen T, Rasmussen S, Nielsen PT. Faster recovery without the use of a tourniquet in total knee arthroplasty. Acta Orthop. 2014;85:422-6.

90. Tai TW, Lin CJ, Jou IM, Chang CW, Lai KA, Yang CY. Tourniquet use in total knee arthroplasty: a meta-analysis. Knee Surg Sport Traumatol Arthrosc. 2011;19:1121-30

91. Harsten A, Bandholm T, Kehlet H, Toksvig-Larsen S. Tourniquet versus no tourniquet on knee-extension strength early after fast-track total knee arthroplasty; a randomized controlled trial. Knee. 2015;22:126-30.

92. Concina C, Crucil M, Fabbro S, Gherlinzoni F. Do tourniquet and drainage influence fast track in total knee arthroplasty? Our results in 151 cases. Acta Biomed. 2019;90(1-S):123-9.

93. Rantasalo MT, Palanne R, Juutilainen K, Kairaluoma P, Linko R, Reponen E, Helkamaa T, Vakkuri A, Olkkola KT, Madanat R, Skants NKA. Randomised controlled study comparing general and spinal anaesthesia with and without a tourniquet on the outcomes of total knee arthroplasty: study protocol. BMJ Open. 2018;8:e025546.

94. Turnbull ZA, Sastow D, Giambrone GP, Tedore T. Anesthesia for the patient undergoing total knee replacement: current status and future prospects. Local Reg Anesth. 2017;10:1-7.

95. Macfarlane AJR, Prasad AG, Chan WWS, Brull R. Does regional anesthesia improve outcome after total knee arthroplasty? A systematic review. $\mathrm{Br}$ J Anaesth. 2009;103:335-45.

96. Hu S, Zhang ZY, Hua YQ, Li J, Cai ZD. A comparison of regional and general anaesthesia for total replacement of the hip or knee: a meta-analysis. J Bone Joint Surg Br. 2009;7:935-42.

97. Pugely AJ, Martin CT, Gao Y, Mendoza-Lattes S, Callaghan JJ. Differences in short-term complications between spinal and general anesthesia for primary total knee arthroplasty. J Bone Joint Surg Am. 2013;95:193-9.

98. Macfarlane AJR, Prasad AG, Chan WWS, Brull R. Does regional anesthesia improve outcome after total knee arthroplasty? Clinic Orthop Related Res. 2009;467:2379-40.

99. Haughom BD, Schairer WW, Nwachukwu BU, Hellman MD, Levine BR. Does neuraxial anesthesia decrease transfusion rates following total hip arthroplasty? J Arthroplasty. 2015;30:116-20.

100. Rashig S, Finegan BA. The effect of spinal anesthesia on blood transfusion rate in total joint arthroplasty. Can J Surg. 2006;49:391-6.

101. Harsten A, Kehlet H, Toksvig-Larsen S. Recovery after total intravenous general anaesthesia or spinal anaesthesia for total knee arthroplasty: a randomized trial. Br J Anaesth. 2013;111:391-9.

102. Sharrock NE, Mineo R, Urquhart B, Salvati EA. The effect of two level of hypotension on intraoperative blood loss during total hip arthroplasty performed under lumbar epidural anesthesia. Anesth Analg. 1993;76:580-4

103. Danninger T, Stundner O, Ma Y, Bae JJ, Memtsoudis SG. The impact of hypothensive epidural anaesthesia on distal and proximal tissue perfusion in patients undergoing total hip arthroplasty. J Anesth Clin Res. 2013;4:366.

104. Kiss H, Raffl M, Neumann D, Hutter J, Dorn U. Epinephrine-augmented hypothensive epidural anesthesia replaces tourniquet use in total knee replacement. Clin Orthop Relat Res. 2005:436:184-9.

105. Juelsgaard P, Larsen UT, Sørensen JV, Madsen F, Søballe K. Hypotensive epidural anesthesia in total knee replacement without tourniquet: reduced blood loss and transfusion. Reg Anesth Pain Med. 2001;26:105-10.

106. Lerman DM, Rapp TB. Minimizing blood loss in orthopaedic surgery the role of antifibrinolytics. Bull Hosp Jt Dis (2013). 2015;73:83-9.3.
107. Eubanks JD. Antibrinolytics in major orthopaeedic surgery. J Am Acad Orthop Surg. 2010;18:132-8.

108. Meeran H. Should antifibrinolytics be used in orthopaedic surgery? Hosp Med. 2003;64:190

109. Sepah YJ, Umer M, Ahmad T, Nasim F, Chaudhry MU, Umar M. Use of tranexamic acid is a cost effective method in preventing blood loss during and after total knee replacement. J Orthop Surg Res. 2011;6:22.

110. Martin K, Wiesner G, Breuer T, Lange R, Tassani P. The risks of aprotinin and tranexamic acid in cardiac surgery: a one-year follow-up of 1188 consecutive patients. Anesth Analg. 2008;107:1783-90.

111. Fergusson DA, Hébert PC, Mazer CD, Fremes S, Mac Adams C, Murkin JM, Teoh K, Duke PC, Arellano R, Blajchman MA, Bussières JS, Coté D, Karski J, Martineau R, Robblee JA, Rodger M, Wells G, Clinch J, Pretorius R, BART Investigators. A comparison of aprotinin and lysone analogues in high-risk cardiac surgery. N Engl J Med. 2008;358:2319-31.

112. Mangano DT, Tudor IC, Dietzel C. Multicenter study of perioperative ischemia research group, ischemia research and education foundation. The risk associated with aprotinin in cardiac surgery. N Engl J Med. 2006;354: 353-65.

113. Yang ZG, Chen WP, Wu LD. Effectiveness and safety of tranexamic acid in reducing blood loss in total knee arthroplasty: a meta-analysis. J Bone Joint Surg Am. 2012;94:1153-9.

114. Oremus K, Sostaric S, Trkulja V, Haspl M. Influence of tranexamic acid on postoperative autologous blood retransfusion in primary total hip and knee arthroplasty: a randomized controlled trial. Transfusion. 2014;54:31-41.

115. Meena S, Benazzo F, Dwivedi S, Ghiara M. Topica versus intravenous tranexamic acid in total knee arthroplasty. J Orthop Surg (Hong Kong). 2017:25:2309499016684300.

116. Zhang $P$, Liang $Y$, Chen $P$, Fang Y, He J, Wang J. Intravenous versus topical tranexamic acid in primary total hip replacement. A meta-analysis. Medicine (Baltimore). 2016;95:e5573.

117. Drosos Gl, Ververidis A, Valkanis C, Tripsianis G, Stavroulakis E, Vogiatzaki T, Kazakos K. A randomized comparative study of topical versus intravenous tranexamic acid administration in enhanced recovery after surgery (ERAS) total knee replacement. J Orthop. 2016;13:127-31.

118. Tzatzairis TK, Drosos GI, Kotsios SE, Ververidis AN, Vogiatzaki TD, Kazakos K Intravenous vs topical tranexamic acid in total knee arthroplasty without tourniquet application: a randomized controlled study. J Arthroplasty. 2016; 11:2465-70.

119. Sun $X$, Dong $Q$, Zhang YG. Intravenous versus topical tranexamic acid in primary total hip replacement: A systematic review and meta-analysis. Int J Surg. 2016;32:10-8.

120. Hsu CH, Lin PC, Kuo FC, Wang JW. A regime of two intravenous injections of tranexamic acid reduces blood loss in minimally invasive total hip arthroplasty: a prospective randomised double-blind study. Bone Joint J. 2015;97-B:905-10.

121. Xie J, Ma J, Yao H, Yue C, Pei F. Multiple boluses of intravenous tranexamic acid to reduce hidden blood loss after primary total knee arthroplasty without tourniquet: a randomized clinical trial. J Arthroplasty. 2016:31:2458-64.

122. Thipparampall AK, Gurajala I, Gopinath R. The effect of different dose regimens of tranexamic acid in reducing blood loss during hip surgery. Indian J Anaesth. 2017;61:235-9.

123. Chen JY, Chia SL, Lo NN, Yeo SJ. Intra-articular versus intravenous tranexamic acid in primary total knee replacement. Ann Transl Med. 2015;3:33.

124. Soni A, Saini R, Gulati A, Paul R, Bhatty S, Rajoli SR. Comparison between intravenous and intra-articular regimens of tranexamic acid in reducing blood loss during total knee arthroplasty. J Arthroplasty. 2014; 29:1525-7.

125. Maniar RN, Kumar G, Singhi T, Nayak RM, Maniar PR. Most effective regimen of tranexamic acid in knee arthroplasty: a prospective randomized controlled study in 240 patients. Clin Orthop Related Res. 2012;470:2605-12.

126. Lin SY, Chen CH, Fu YC, Huang PJ, Chang JK, Huang HT. The efficacy of combined use of intraarticular and intravenous tranexamic acid on reducing blood loss and transfusion rate in total knee arthroplasty. J Arthroplasty. 2015;30:776-80.

127. Shang J, Wang H, Zheng B, Rui M, Wang Y. Combined intravenous and topical tranexamic acid versus intravenous use alone in primary total knee and hip arthroplasty: A meta-analysis of randomized controlled trials. Int J Surg. 2016;36(Pt A):324-9. 
128. Duncan CM, Gillette BP, Jacob AK, Sierra RJ, Sanchez-Sotelo J, Smith HM. Venous thromboembolism and mortality associated with tranexamic acid use during total hip and knee arthroplasty. J Arthroplasty. 2015;30:2726.

129. Husted H. Fast-track hip and knee arthroplasty: clinical and organizational aspects. Acta Orthop Suppl. 2012;83:1-39.

130. McDonald DA, Siegmeth R, Deakin AH, Kinninmonth AW, Scott NB. An enhanced recovery programme for primary total knee arthroplasty in the United Kingdom—follow up at one year. Knee. 2012;19:525-9.

131. Malviya A, Martin K, Harper I, Muller SD, Emmerson KP, Partington PF, Reed MR. Enhanced recovery program for hip and knee replacement reduces death rate. Acta Orthop. 2011;82:577-81.

132. Nielsen CS, Jans $\varnothing$, Ørsnes T, Foss NB, Troelsen A, Husted H. Combined intra-articular and intravenous acid reduces blood loss in total knee arthroplasty: a randomized, double-blind, placebo-controlled trial. J Bone Joint Surg Am. 2016;98:835-41.

133. Jans $\varnothing$, Grevstad U, Mandøe $H$, Kehlet $H$, Johansson PI. A randomized trial of the effect of low dose epinephrine infusion in addition to tranexamic acid on bloos loss during total hip arthroplasty. Br J Anaesth. 2016;116:357-62.

134. Kelley TC, Tucker KK, Adams MJ, Dalury DF. Use of tranexamic acid results in decreased blood loss and decreased transfusions in patients undergoing staged total knee arthroplasty. Transfusion. 2014;54:26-30.

135. Gao F, Ma J, Sun W, Guo W, Li Z, Wang W. Topical fibrin sealant versus intravenous tranexamic acid for reducing blood loss following total knee arthroplasty: a systematic review and meta-analysis. Int J Surg. 2016;32:31-7.

136. Choufani C, Barbier O, Bajard X, Ollat D, Versier G. Medical and economic impact of a haemostatic sealant on the rate of transfusion after total knee arthroplasty. Transfus Clin Biol. 2015;22:22-9.

137. Randelli F, D'Anchise R, Ragone V, Serrao L, Cabitza P, Randelli P. Is the newest fibrin sealant an effective strategy to reduce blood loss after total knee arthroplasty? A randomized controlled study. J Arthroplasty. 2014;29: $1516-20$.

138. van Bodegom-Vos L, Voorn VM, So-Osman C, Vliet Vlieland TP, Dahan A, Koopman-van Gemert AW, Vehmeijer SB, Nelissen RG, Marang-van de Mheen PJ. Cell salvage in hip and knee arthroplasty: a meta-analysis of randomized controlled trials. J Bone Joint Surg Am. 2015;97:1012-21.

139. Haien Z, Yong J, Baoan M, Mingjun G, Qingyu F. Post-operative autotransfusion in total hip or knee arthroplasty: a meta-analysis of randomized controlled trials. PLoS One. 2013:8:e55073 Epub 2013 Jan 25.

140. Markar SR, Jones GG, Karthikesalingam A, Segaren N, Patel RV. Transfusion drains versus suction drains in total knee replacement: meta-analysis. Knee Surg Sports Traumatol Arthrosc. 2012;20:1766-72 Epub 2011 Nov 10.

141. Carless PA, Henry DA, Moxey AJ, O'Connell D, Brown T, Fergusson DA. Cell salvage for minimising perioperative allogenic blood transfusion. Cochrane Database Sys Rev. 2010;4:CD001888 Epub 2010 Apr 14

142. Groenewold MD, Gribnau AJ, Ubbink DT. Topical haemostatic agents for skin wounds: a systematic review. BMC Surg. 2011;11:15.

143. Anderson LA, Engel GM, Bruckner JD, Stoddard GJ, Peters CL. Reduced bloos loss after total knee arthroplasty with local injection of bupivacaine and epinephrine. J Knee Surg. 2009:22:130-6.

144. Yang $\mathrm{CY}$, Chang CW, Chen YN, Chang CH. Intra-articular injection of bupivacaine and epinephrine does not save blood loss after total knee arthroplasty. BJJ. 2016;98(Supp.1):68.

145. Zeng WN, Liu JL, Wang FY, Chen C, Zhou Q, Yang L. Low-dose epinephrine plus tranexamic acid reduces early postoperative blood loss and inflammatory response: a randomized controlled trial. J Bone Joint Surg Am. 2018;100:295-304

146. Morin AM, Wulf H. High volume local infiltration analgesia (LIA) for total hip and knee arthroplasty: a brief review on the current status. Anaesthesiol Intensivmed Notfallmed Schmerzther. 2011;46:84-6.

147. Andersen $L \varnothing$, Kehlet $H$. Analgesic efficacy of local infiltration analgesia in hip and knee arthroplasty: a systematic review. Br J Anaesth. 2014; 113:360-74

148. Voorn VMA, Marang-van de Mheen PJ, van der Hout A, Hofstede SN, SoOsman C, van den Akker-van Marle ME, Kaptein AA, Stijnen T, Koopman-van Gemert AWMM, Dahan A, Vliet Vlieland TPMM, Nelissen RGHH, van Bodegom-Vos L. The effectiveness of a de-implementation strategy to reduce low-value blood management techniques in primary hip and knee arthroplasty: a pragmatic cluster-randomized controlled trial. Implement Sci. 2017;12:72.

149. Nielsen CS, Gromov K, Jans $\varnothing$, Troelsen A, Husted H. No effect of a bipolar sealer on total blood loss or blood transfusion in nonseptic revision knee arthroplasty - a prospective study with matched retrospective controls. J Arthroplasty. 2017;32:177-82.

150. Rosenthal BD, Haughom BD, Levine BR. A retrospective analysis of hemostatic tehcniques in primary total knee arthroplasty: traditional electrocautery, bipolar sealer, and argon beam coagulation. Am J Orthop (Belle Mead NJ). 2016:45:E187-91.

151. Huang Z, Ma J, Shen B, Yang J, Zhou Z, Kang P, Pei F. Use of a bipolar blood-sealing system during total joint arthroplasty. Orthopedics. 2015;38: 757-63.

152. Kamath AF, Austin DC, Derman PB, Clement RC, Garino JP, Lee GC. Salinecoupled bipolar sealing in simultaneous bilateral total knee arthroplasty. Clin Orthop Surg. 2014;6:298-304.

153. Marulanda GA, Krebs VE, Bierbaum BE, Goldberg VM, Ries M, Ulrich SD, Seyler TM, Mont MA. Hemostasis using a bipolar sealer in primary unilateral total knee arthroplasty. Am J Orthop (Belle Mead NJ). 2009;38:E179-83.

154. Samdani AF, Torre-Healy A, Asghar J, Herlich AM, Betz RR. Strategies to reduce blood loss during posterior spinal fusion for neuromuscular scoliosis: a review of current techniques and experience with a unique bipolar electrocautery device. Surg Technol Int. 2008;17:243-8.

155. Yim AP, Rendina EA, Hazelrigg SR, Chow LT, Lee TW, Wan S, Arifi AA. A new technological approach to nonanatomical pulmonary resection: saline enhanced thermal sealing. Ann Thorac Surg. 2002;74:1671-6.

156. Saltzman BM, Oni JK. A review of bipolar sealer use in modern total joint arthroplasty. Ann Orthop Rheumtaol. 2014;2:1015.

157. Gardner MJ, Demetrakopoulos D, Klepchick PR, Mooar PA. The efficacy of autologous platelet gel in pain control and blood loss in total knee arthroplasty. An analysis of the haemoglobin, narcotic requirement and range of motion. Int Orthop. 2007;31:309-13.

158. Guerreiro JP, Danieli MV, Queiroz AO, Deffune E, Ferreira RR. Platelet-rich plasma (PRP) applied during total knee arthroplasty. Rev Bras Orthop. 2015; 50:186-94.

159. Tingstad EM, Bratt SN, Hildenbrand KJ, O'Malley BA, Mitchell ER, Gaddis CE, Jacobson CA. Platelet-rich plasma does not decrease blood loss in total knee arthroplasty. Orthopedics. 2015;38:e434-6.

160. Schonauer C, Tessitore E, Barbagallo G, Albanese V, Moraci A. The use of local agents: bone wax, gelatin, collagen, oxidized cellulose. Eur Spine J. 2004;13(Suppl 1):S89-96.

161. Moo IH, Chen JYQ, Pagkaliwaga EH, Tan SW, Poon KB. Bone wax is effective in reducing blood loss after total knee arthroplasty. J Arthroplasty. 2017;32: 1483-7.

162. Solomon LB, Guevara C, Büchler L, Howie DW, Byard RW, Beck M. Does bone wax induce a chronic inflammatory articular reaction? Clin Orthop Relat Res. 2012;470:3207-12.

163. Qian T, Ping S, Gang Z, Hua-Zi X, Hai-Xiao L. Extramedullary versus intramedullary femoral alignment technique in total knee arthroplasty: a meta-analysis of randomized controlled trials. J Orthop Surg Res. 2017:12:82.

164. Meding JB, Berend ME, Ritter MA, Galley MR, Malinzak RA. Intramedullary vs extramedullary femoral alignment guides: a 15-year follow-up of survivorship. J Arthroplasty. 2011;26:591-5.

165. Sehat KR, Evans RL, Newman JH. Hidden blood loss following hip and knee arthroplasty. Correct management of blood loss should take hidden loss into account. J Bone Joint Surg Br. 2004;86:561-5.

166. Senthil Kumar G, Von Arx OA, Pozo JL. Rate of blood loss over 48 hours following total knee replacement. Knee. 2005;12:307-9.

167. Brock TM, Sprowson AP, Muller S, Reed MR. Short-stretch inelastic compression bandage in knee swelling following total knee arthroplasty study (STICKS): study protocol for a randomised controlled feasibility study. Trials. 2015;16:87.

168. Andersen L $\varnothing$, Husted H, Otte KS, Kristensen BB, Kehelt HH. A compression bandage improves local infiltration analgesia in total knee arthroplasty. Acta Orthop. 2008;79:806-11.

169. Cheung A, Lykostratis $\mathrm{H}$, Holloway I. Compression bandaging improves mobility following total knee replacement in an enhanced recovery setting. J Perioper Pract. 2014;24:84-6.

170. Pinsornsak $P$, Chumchuen S. Can a modified Robert Jones bandage after knee arthroplasty reduce blood loss? A prospective randomized controlled trial. Clin Orthop Relat Res. 2013;471:1677-81.

171. Munk S, Jensen NJ, Andersen I, Kehlet J, Hansen TB. Effect of compression therapy on knee swelling and pain after total knee arthroplasty. Knee Surg Sports Traumatol Arthrosc. 2013;21:388-92. 
172. Ni SH, Jiang WT, Guo L, Jin YH, Jiang TL, Zhao Y, Zhao J. Cryotherapy on postoperative rehabilitation of joint arthroplasty. Knee Surg Sports Traumatol Arthrosc. 2015;23:3354-61.

173. Adie S, Naylor JM, Harris IA. Cryotherapy after total knee arthroplasty a systemic review and meta-analysis of randomized controlled trials. J Arthroplasty. 2010;25:709-15.

174. Ruffilli A, Castagnini F, Traina F, Corneti I, Fenga D, Giannini S, Faldini C. Temperature-controlled continuous cold flow device after total knee arthroplasty: a randomized controlled trial study. J Knee Surg. 2017;30: 675-81.

175. Wu Y, Yang T, Zeng Y, Si H, Li C, Shen B. Effect of different postoperative limb positions on blood loss and range of motion in total knee arthroplasty: an updated meta-analysis of randomized controlled trials. Int J Surg. 2017; 37:15-23.

176. Faldini C, Traina F, De Fine M, Pedrini M, Sambri A. Post-operative limb position can influence blood loss and range of motion after total knee arthroplasty: a systematic review. Knee Surg Sports Traumatol Arthrosc. 2015;23:852-9

177. Yang Y, Yong-Ming L, Pei-jian D, Jia L, Ying-ze Z. Leg position influences early blood loss and functional recovery following total knee arthroplasty: a randomized study. Int J Surg. 2015;23(Pt A):82-6.

178. Muňoz M, Ariza D, Campos A, Martin-Montańez E, Pavía J. The cost of postoperative shed blood salvage after total knee arthroplasty: an analysis of 1 . 093 consecutive procedures. Blood Transfus. 2013;11:260-71.

179. Kim YH, Cho SH, Kim RS. Drainage versus nondrainage in simultaneous bilateral total knee arthroplasties. Clin Orthop Related Res. 1998;347:188-93.

180. Kim YH, Cho SH, Kim RS. Drainage versus nondrainage in simultaneous bilateral total hip arthroplasties. J Arthroplasty. 1998;13:156-61.

181. Tai TW, Jou IM, Chang CW, Lai KA, Yang CY. Non-drainage is better than 4hour clamping drainage in total knee arthroplasty. Orthopedics. 2010;33 Epub 2010 Mar 10.

182. Esler CN, Blakeway C, Fiddian NJ. The use of a closed-suction drain in total knee arthroplasty. A prospective, randomised study. J Bone Joint Surg Br. 2003:85:215-7.

183. Mengal B, Aebi J, Rodriguez A, Lemaire R. A prospective randomized study of wound drainage versus non-drainage in primary total hip or knee arthroplasty. Rev Chir Orthop Reparatrice Appar Mot. 2001;87:29-39.

184. Stucinskas J, Tarasevicius S, Cebatorius A, Robertsson O, Smailys A, Wingstrand $\mathrm{H}$. Conventional drainage versus four hour clamping drainage after total knee arthroplasty in severe osteoarthritis: a prospective, randomised trial. Int Orthop. 2009;33:1275-8.

185. Raleigh E, Hing CB, Hanusiewicz AS, Fletcher SA, Price R. Drain clamping in knee arthroplasty, a randomized controlled trial. ANZ J Surg. 2007;77:333-5.

186. Yamada K, Imaizumi T, Uemura M, Takada N, Kim Y. Comparison between 1hour and 24-hours drain clamping using diluted epinephrine solution after total knee arthroplasty. J Arthroplasty. 2011;16:458-62.

187. Pornrattanamaneewong C, Narkbunnam R, Siriwattanasakul P, Chareancholvanich K. Three-hour interval drain clamping reduces postoperative bleeding in total knee arthroplasty: a prospective randomized controlled trial. Arch Orthop Trauma Surg. 2012;132:1059-63.

188. Liao L, Chen Y, Tang Q, Chen XY, Wang WC. Tranexamic acid plus drainclamping can reduce blood loss in total knee arthroplasty: A systematic review and meta-analysis. Int J Surg. 2018;52:334-41.

189. Chareancholvanich $K$, Siriwattanasakul $P$, Narkbunnam $R$, Pornrattanamaenewong C. Temporary clamping of drain combined with tranexamic acid reduce blood loss after total knee arthroplasty: a prospective randomized controlled trial. BMC Musculoskelet Disord. 2012;13: 124.

190. Zan P, Yao JJ, Fan L, Yang Y, Zhou Z, Wu Z, Zhu C, Yang D, Li G. Efficacy of a four-hour drainage clamping technique in the reduction of blood loss following total hip arthroplasty: a prospective cohort study. Med Sci Monit. 2017;23:2708-14

191. Xu X, Li X, Liu W, Wang Z. Longtime soaking of high concentration tranexamic acid in total hip arthroplasty: A prospective randomized controlled trial in 224 patients. Pak J Med Sci. 2015;31:1306-11.

192. Zhang S, Xu B, Huang Q, Yao H, Xie J, Pei F. Early Removal of drainage tube after fast-track primary total knee arthroplasty. J Knee Surg. 2017;30:571-6.

193. Arsoy D, Giori NJ, Woolson ST. Mobile compression reduces bleedingrelated readmissions and wound complications after THA and TKA. Clin Orthop Relat Res. 2018;476:381-7.
194. Geerts WH, Pineo GF, Heit JA, Berqqvist D, Lassen MR, Colwell CW, Ray JG. Prevention of venous thromboembolism: the Seventh ACCP Conference on Antithrombotic and Thrombolytic Therapy. Chest. 2004;126:338S-400S.

195. Nicolaides AN, Breddin HK, Fareed J, Goldhaber S, Haas S, Hull R, Kalodiki E, Myers K, Samama M, Sasahara A, Cardiovascular disease educational and research trust and the international union of angiology. Prevention of venous thromboembolism. International Consensus Statement. Guidelines compiled in accordance with the scientific evidence. Int Angiol. 2001;20:1-37.

196. Tyagi V, Tomaszwewski P, Lukasiewicz A, Theriault S, Pelker R. The role of intraoperative intermittend pneumatic compression devices in venous thromboembolism prophylaxis in total hip and total knee arthroplasty. Orthopedics. 2018;41:e98-e103.

197. Caprini JA. Thrombosis risk assessment as a guide to quality patient care. Dis Mon. 2005:51:70-8.

198. Husted H, Otte KS, Kristensen BB, Ørsnes T, Wong C, Kehlet H. Low risk of thromboembolic complications after fast-track hip and knee arthroplasty. Acta Orthop. 2010;81:599-605.

199. Chandrasekaran S, Ariaretnam SK, Tsung J, Dickison D. Early mobilization after total knee replacement reduces the incidence of deep venous thrombosis. ANZ J Surg. 2009;79:526-9.

200. Wellman SS, Murphy AC, Gulcynski D, Murphy SB. Implementation of an accelerated mobilization protocol following primary total hip arthroplasty: impact on length of stay and disposition. Curr Rev Musculoskelet Med. 2011:4:84-90.

201. Bonutti PM, Sodhi N, Patel YH, Sultan AA, Khlopas A, Chughtai M, Kolisek FR, Williams N, Mont MA. Novel venous thromboembolic disease (VTED) prophylaxis for total knee arthroplasty-aspirin and fish oil. Ann Transl Med. 2017;5(Suppl 3):S30

202. Roberts M, Ahya R, Greaves M, Maffulli N. A one-centre prospective audit of peri- and postoperative blood loss and transfusion practice in patients undergoing hip or knee replacement surgery. Ann R Coll Surg Engl. 2000;82:4-8

203. Voorn VMA, van Bodegom-Vos L, So-Osman C. Towards a systematic approach for (de)implementation of patient blood management strategies. Transfus Med. 2018;28:158-67.

\section{Publisher's Note}

Springer Nature remains neutral with regard to jurisdictional claims in published maps and institutional affiliations.

\section{Ready to submit your research? Choose BMC and benefit from:}

- fast, convenient online submission

- thorough peer review by experienced researchers in your field

- rapid publication on acceptance

- support for research data, including large and complex data types

- gold Open Access which fosters wider collaboration and increased citations

- maximum visibility for your research: over $100 \mathrm{M}$ website views per year

At $\mathrm{BMC}$, research is always in progress.

Learn more biomedcentral.com/submission 